\title{
Penyajian Tema dalam Alih Wahana Game dan Serial Netflix Castlevania
}

\author{
Kriswanda Krishnapatria \\ Program Studi Sastra Inggris, Fakultas Ilmu Budaya, Universitas Padjadjaran \\ e-mail: kriswanda.krishnapatria@ unpad.ac.id
}

\begin{abstract}
Abstrak
Artikel ini mendiskusikan topik tentang bagaimana tema utama disajikan dalam alih wahana Castelevania III: Dracula's Curse dari game klasiknya ke serial Netflix dengan menganalisis aspek kesusastraannya seperti alur, sudut pandang, serta simbolisme. Pada bagian simbolisme, pendekatan semiotik trikotomi Peirce digunakan dalam melakukan analisis. Metode penelitian yang digunakan adalah deskriptif analitik. Dengan menganalisis perubahan aspekaspek dalam alih wahana ini, peneliti menemukan bahwa ketiga elemen intrinsik yang disebutkan di atas mendukung tema utama antara game orisinil dan serial Netflixnya. Sebagai tambahan, game klasiknya ternyata menampilkan tema utama dengan lebih kuat serta menyajikan Dracula sebagai tokoh yang lebih kejam dibandingkan serial animasinya.

Kata kunci: Alih Wahana, Castlevania III: Dracula's Curse, elemen intrinsik, Netflix, penyajian tema

Abstract

In this article, the discussed topic is how the theme is presented in the adaptation between Castlevania III: Dracula's Curse and its Netflix adaptation through literary elements of plot, point of view, and symbolism. Furthermore, Peirce's semiotics trichotomy was applied in analysing the symbolism. The method used in this paper is descriptive analytical. By analysing the element changes in the adaptation study, it is found that the aspects mentioned above do support the main theme between the original game and Netflix series. Additionally, it appears that the classic game depicts the main theme stronger, and presents Dracula as a more villainous character than the animated series.
\end{abstract}

Keywords: Adaptation, Castlevania III: Dracula's Curse, literary elements, Netflix, theme presentation 


\section{Pendahuluan}

Seiring dengan semakin populernya video game, semakin banyak pula adaptasinya menjadi berbagai media seperti film dan fiksi. Damono (2018) memiliki istilah alih wahana untuk menyebut transformasi dari satu wahana (media) ke wahana yang lain. Lebih lanjut Hutcheon (2012) menjelaskan bahwa, "Adaptations are everywhere today: on the television and movie screen, on the musical and dramatic stage, on the Internet, in novels and comic books, in your nearest theme park and video arcade." Lebih dari itu, kendatipun kecenderungan perkembangan video game senantiasa berubah, game bergenre horor mungkin tetap menjadi salah satu yang istimewa karena tidak pernah kehilangan penggemarnya.

Baik karena nostalgia dan/atau berkeinginan mendapatkan profit dari nama besar franchise game horror, cukup banyak alih wahana film horor yang diadaptasi dari video game. Meskipun Silent Hill (TriStar Pictures, 2006; Open Road Films, 2012) dan Resident Evil (Screen Gems, 2002, 2004, 2007, 2010, 2012, 2017) adalah film yang cukup laris di pasaran, tidak semua audiens mengetahui fakta bahwa keduanya merupakan adaptasi dari video game yang sama suksesnya. Rouse III (2009) berpendapat bahwa kunci keberhasilan genre horor baik dalam game maupun film adalah memanfaatkan kombinasi ketakutan serta ketegangan yang dialami tokoh dalam cerita yang kemudian dirasakan oleh pemain atau penonton.

Jauh sebelum lahirnya sastra Gotik pada abad ke-18 dan 19, tema horor yang melibatkan rasa takut pembaca sudah hadir dalam legenda, dongeng, ataupun cerita rakyat di Eropa (Therrien, 2009). Makhluk siluman jahat seperti warewolf, succubus, dan imp tidak jarang mengisi cerita-cerita fiksi di abad pertengahan, dan ini bermakna bahwa topik demonologi bahkan telah hadir di abad kegelapan. Fiksi horor Gotik pada akhirnya dapat mengukuhkan posisinya dalam prosa sebagai salah satu genre fiksi yang cukup populer di masyarakat. Literatur seperti Frankenstein (Mary Shelley, 1818), The Picture of Dorian Gray (Oscar Wilde, 1891), dan The Fall of The House of Usher (Edgar Allan Poe, 1839) telah mendapatkan banyak atensi dari pembaca umum ataupun dari kalangan akademik hingga kemudian berkontribusi pada lahirnya narasi-narasi serupa dalam berbagai media hingga masa kini.

Genre horor yang telah berkembang saat ini merupakan sebuah evolusi selama berabad-abad dan akan terus berkembang. Akan tetapi, tidak semua narasi yang lahir 
terutama di era milenium saat ini adalah cerita yang benar-benar baru dan orisinil. Tidak jarang cerita horor yang dikonsumsi oleh audiens dan pembaca akhir-akhir ini dibangkitkan kembali dari 'kuburan'nya dengan kemasan cerita serta platform media yang berbeda.

Seiring dengan perkembangan teknologi informasi dan kecenderungan dalam mengkonsumsi hiburan di masyarakat, novel fiksi dan film bioskop tidak lagi menjadi primadona sejak kehadiran layanan streaming. Tidak seperti layanan TV kabel pada umumnya, layanan streaming memungkinkan pelanggannya menonton acara yang diinginkannya sesuai permintaan saat itu juga (video on demand) tanpa ada gangguan iklan. Akan tetapi dari beragam pilihan layanan streaming yang ada saat ini seperti YouTube Premium, Disney+ Hotstar, atau HBO GO bisa dikatakan Netflix adalah salah satu layanan streaming terbesar dan terpopuler, karena pada April 2019 Netflix tercatat memiliki lebih dari 148 juta langganan berbayar di seluruh dunia (Netflix, 2019).

Selain menyajikan film-film laris yang pernah tayang di bioskop dalam layanannya, Netflix juga memproduksi film atau serial orisinilnya sendiri yang tidak bisa ditemukan di platform lain, dan ini menjadi salah satu daya tariknya. Pada bulan Juli 2017 layanan streaming Netflix secara eksklusif merilis musim pertama seri animasi berjudul Castlevania yang merupakan adaptasi dari game aslinya. Vo (2017) menjelaskan bahwa serial Castlevania dari Netflix berhasil mematahkan sebuah kutukan yang ada dengan menjadi adaptasi video game pertama yang mendapatkan peringkat tinggi (7.39/10) pada situs ulasan yang cukup populer: Rotten Tomatoes. Karena kesuksesannya, musim kedua serial ini kemudian dirilis pada tahun 2018, dan kemudian penggemar animasi horor ini seharusnya dapat cukup berbahagia karena musim ketiganya dirilis pada Maret 2020 pada masa pandemi COVID-19.

Castlevania sejatinya adalah salah satu franchise game yang terinspirasi dari novel Dracula karya Bram Stoker dengan formula side-scrolling action game tersukses yang pernah ada. Adapun serial Castlevania dari Netflix merupakan alih wahana dari game Nintendo Entertainment System (NES) klasik yang berjudul Castlevania III: Dracula's Curse, dirilis pada tahun 1990. Seri video game Castlevania merupakan salah satu franchise horor Gotik yang telah dirilis multi platform dari game konsol rumahan hingga perangkat genggam, dan dalam berbagai wahana mulai dari komik hingga serial animasi. 
Dengan kepopuleran Castlevania, tidak jarang akademisi melakukan kajian dan penelitian dengan topik yang berbeda-beda. Penulis meyakini, siapapun yang mengetahui dan pernah memainkan game Castlevania pasti masih mengingat lagu yang berjudul "Vampire Killer", dan karena lagu ini dianggap salah satu lagu 8-bit terbaik yang pernah ada, Edwards (2006) secara khusus membahas aspek musik dalam game Castlevania III yang ikonik dan legendaris. Selain itu, Martin (2011) meneliti ambivalensi dan rekursi tokoh protagonis Alucard dalam game Castlevania: Symphony of the Night. Lebih lanjut, Jowett, Abbott, and Starr (2017) menyebutkan bahwa serial Castlevania dari Netflix merupakan masa depan dari alih wahana game horor, dan sepertinya akan lebih banyak cerita hantu yang akan diadaptasi dari video game ke layar televisi.

Meskipun sampai artikel ini ditulis sudah ada beberapa penelitian yang membahas topik Castlevania seperti yang disebutkan di atas, belum ada manuskrip yang secara khusus mengkaji alih wahana dari game Castlevania menjadi serial televisi Netflix, terutama ditinjau dari aspek kesusasteraan beserta elemen-elemen intrinsik narasinya. Oleh karena itu, artikel ini ditulis untuk mengisi kesenjangan penelitian tersebut selain bertujuan untuk menambah khazanah alih wahana itu sendiri. Dan lagi, artikel ini berusaha mengkaji tentang bagaimana tema utama disajikan dalam alih wahana dari game ke serial Netflix Castlevania melalui unsur-unsur intrinsik seperti alur, point of view, dan simbolisme.

Penelitian ini menggunakan metode deskriptif analitik, suatu penelitian untuk memperoleh informasi mengenai suatu fenomena. Hasil penelitian ini kemudian dikumpulkan dan dianalisis untuk membuat kesimpulan yang logis. Kajian ini tergolong deskriptif karena tujuannya untuk menjelaskan penyajian tema dalam adaptasi Castlevania III: Dracula's Curse pada serial Netflix Castlevania.

Ketika menganalisis representasi tema dalam alih wahana Castlevania dalam kedua media, penulis memainkan game orisinilnya menggunakan program emulator dan kemudian menonton serial animasinya di Netflix. Data dari kedua wahana tersebut kemudian dikumpulkan dan dikaji dengan membandingkan serta mengkontraskan bagaimana tema utama disajikan melalui unsur-unsur intrinsik plot, sudut pandang, dan simbolisme.

\section{Pembahasan}




\section{Tema Castlevania}

Tema utama dalam game Castlevania III: Dracula's Curse adalah konflik antara good dan evil atau kebaikan melawan kejahatan. Hal ini dapat dengan jelas dilihat pada bagian prolog sebelum permainan dimulai. Dracula sebagai penjahat utama dalam game ini diceritakan ingin menciptakan sebuah dunia buruk yang dipenuhi dengan kejahatan, dan Trevor Belmont sebagai protagonis utama diminta oleh penduduk Wallachia yang tertindas dan ketakutan untuk melawan Dracula dan pasukannya. Senada dengan gamenya, serial Castlevania juga memiliki tema yang sama. Hanya saja, dunia dalam serial animasi ini tidak hanya terdikotomi menjadi baik dan buruk, tetapi terdapat juga perasaan cinta dan benci yang tersajikan dalam cerita.

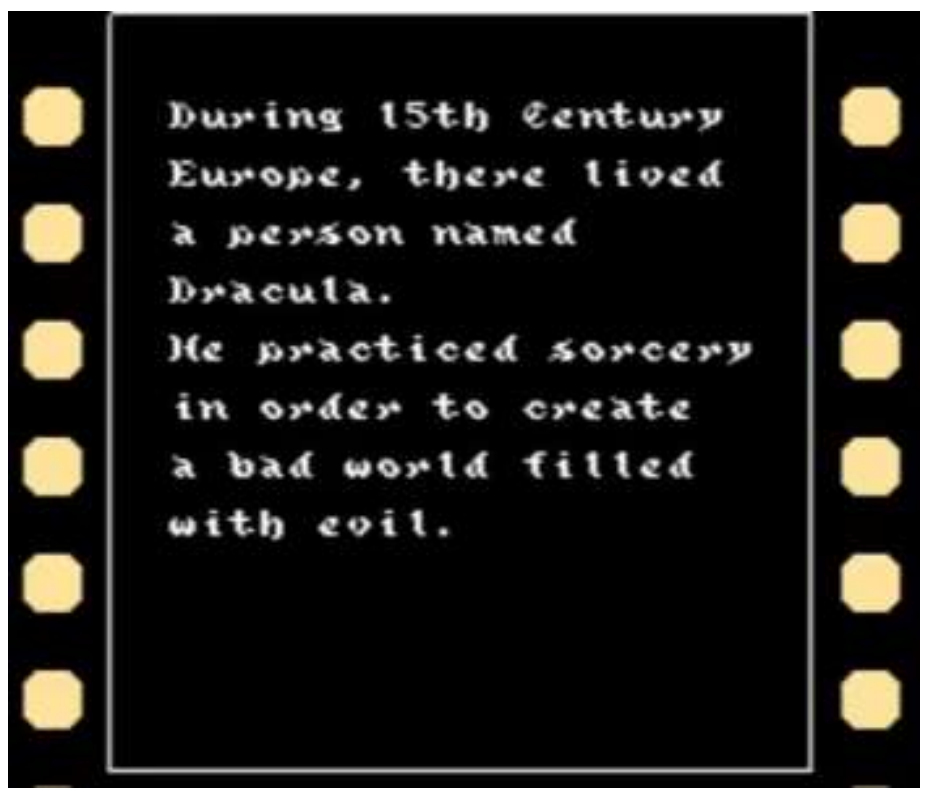

Gambar 1: Castlevania III: Dracula's Curse menyajikan prolog yang memberikan informasi narasi permainan.

Konflik antara kebaikan melawan kejahatan yang mencuat dalam game dan serial Castlevania dapat dilihat dari kontrasnya sifat karakter dalam kedua wahana. Kubu good diwakili oleh figur-figur yang berwatak pengasih, suka menolong, serta sifat-sifat terpuji lainnya, dan beberapa tokoh yang mewakili kubu ini di antaranya Trevor Belmont, Sypha Belnades, Alucard, dan Grant (dalam game saja). Sedangkan kubu evil diwakili oleh karakter dengan sifat jahat, keji, serta sifat-sifat buruk lainnya dan tersajikan melalui tokoh-tokoh seperti Dracula, Cyclops, dan Carmilla (dalam serial Netflix). Sebagai tambahan, selain tema utama yang telah disebutkan di atas, kedua wahana turut 
menyajikan tema-tema tambahan yang ikut menunjang tema utamanya. Tema tambahan tersebut antara lain keangkuhan dan kesombongan, serta persahabatan dan kesetiaan.

Dalam serial animasi Netflix, tema tambahan mengenai keangkuhan dan kesombongan tersaji ketika seorang uskup yang korup dan fanatik menangkap Lisa, istri Dracula, kemudian membakarnya pada tiang salib karena tuduhan sihir. Dracula yang mengetahui tragedi sepulang dari perjalanannya kemudian marah dan bertransformasi menjadi pilar api di tengah kota, mengutuk orang-orang di sana karena telah membunuh istrinya yang seorang dokter tidak berdosa. Keangkuhan sang uskup kemudian ditunjukkan dalam cerita ketika dia menolak eksistensi Dracula serta menganggapnya sebagai mitos belaka.

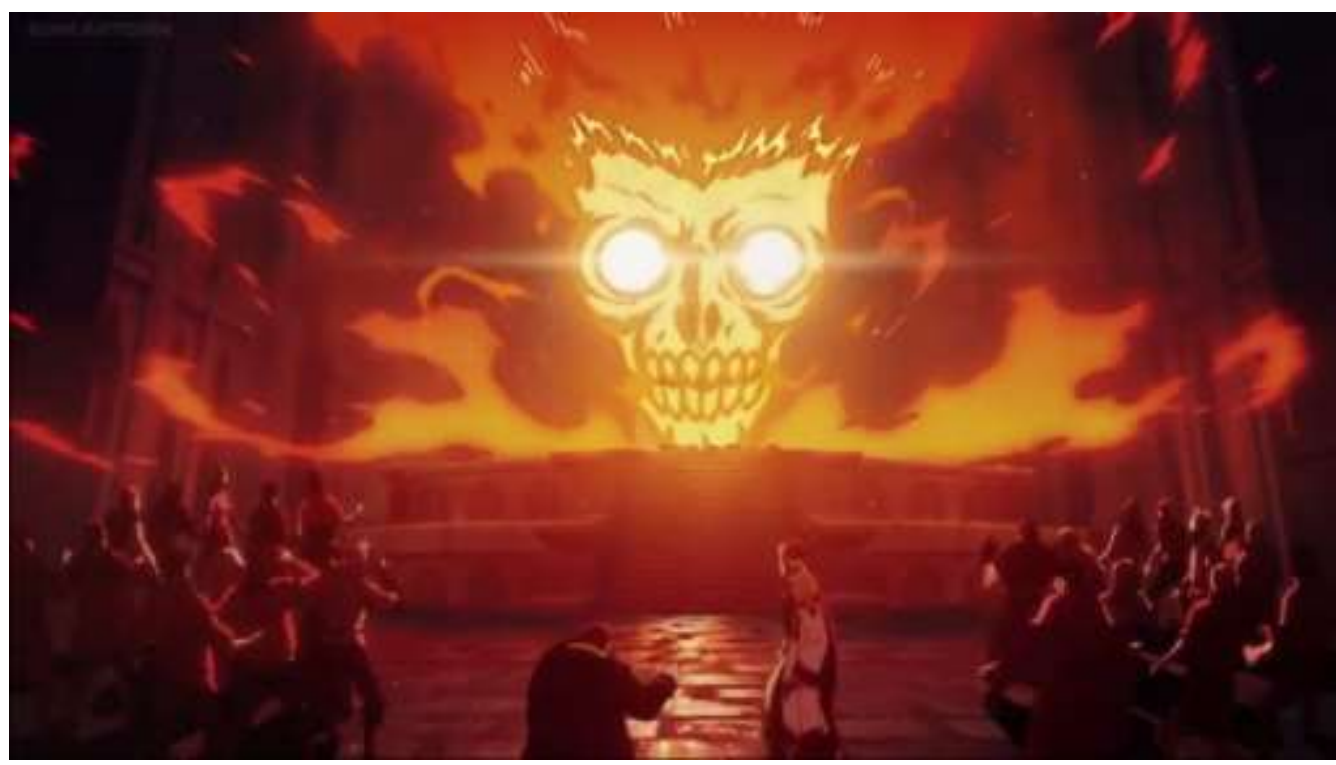

Gambar 2: Dracula termanifestasi dalam api berbicara kepada penduduk Wallachia (Castlevania, "Witchbottle").

"One year. I gave you one year to make your peace with your God. And what do you do? Celebrate the day you killed my wife! One year I gave you while I assembled my armies, and now... I bring your death! You had your chance." Setahun setelah ancamannya diabaikan dan dindahkan oleh penduduk Wallachia, Dracula yang marah dan dendam kemudian mulai membantai para penduduk beserta uskup yang telah menganggap ancamannya sebagai bualan belaka. Dalam hal ini, keangkuhan dan kesombongan seseorang pada akhirnya mengakibatkan malapetaka dan kehancuran bagi dirinya sendiri. Dibandingkan game orisinilnya, ketiadaan adegan yang menjadi pemicu 
utama atas rangkaian persitiwa lainnya dalam serial Castlevania ternyata menyajikan tokoh Dracula secara berbeda di dalam kedua wahana.

Tema tambahan tentang pertemanan dan kesetiaan dapat dilihat dari tali persahabatan yang terjalin antara Trevor dengan deutragonis seiring berjalannya alur. Tidak seperti seri game Castlevania lainnya, alur Castlevania III bersifat non-linear di mana Trevor, sang karakter utama, hanya dapat dibantu oleh salah satu dari tiga karakter pembantu (Sypha, Alucard, atau Gant) yang bisa dimainkan. Permainan yang dihadirkan kemudian sedemikian rupa dirancang agar pemain dapat menggunakan karakter pendamping Trevor secara optimal. Sebagai contoh, ketika Trevor memutuskan untuk memilih Gant sebagai pendamping, maka stage 2-05 dan 2-06 dalam kastil yang dipenuhi roda bergigi dan pendulum raksasa akan menjadi lebih mudah dilalui jika pemain beralih pada Gant karena kemampuan istimewanya yang dapat melompat dua kali serta berjalan di atas dinding. Persahabatan Trevor dan kesetiannya terhadap Gant juga kemudian dikukuhkan kala pemain menamatkan permainan dengan Gant sebagai pendamping: "Both feel their friendship is stronger since they worked together to rid Wallachia city of evil."

Demikian pula dengan adaptasinya, tema persahabatan dan kesetiaan juga ditunjukkan ketika Trevor bertarung dan menahan serangan Minotaur serta iblis lainnya sementara Alucard menggunakan cermin ajaib untuk menemukan kastil Dracula yang kerap berpindah tempat sehingga Sypha dapat mencoba untuk menyelesaikan mantra penguncian. Tindakan kerja sama dan saling mendukung ketiga tokoh protaganis tersebut secara jelas menunjukkan nilai persahabatan mereka karena Trevor dan kedua rekannya saling mengerti akan kemampuan serta tugas masing-masing, dan pada akhirnya mereka dapat menemukan dan mengunci kastil Dracula. Ketiga tokoh ini juga sepenuhnya sadar akan pentingnya menyelematkan Wallachia dari Dracula sehingga tetap setia bersama hingga menghadapi sang antagonis utama. 


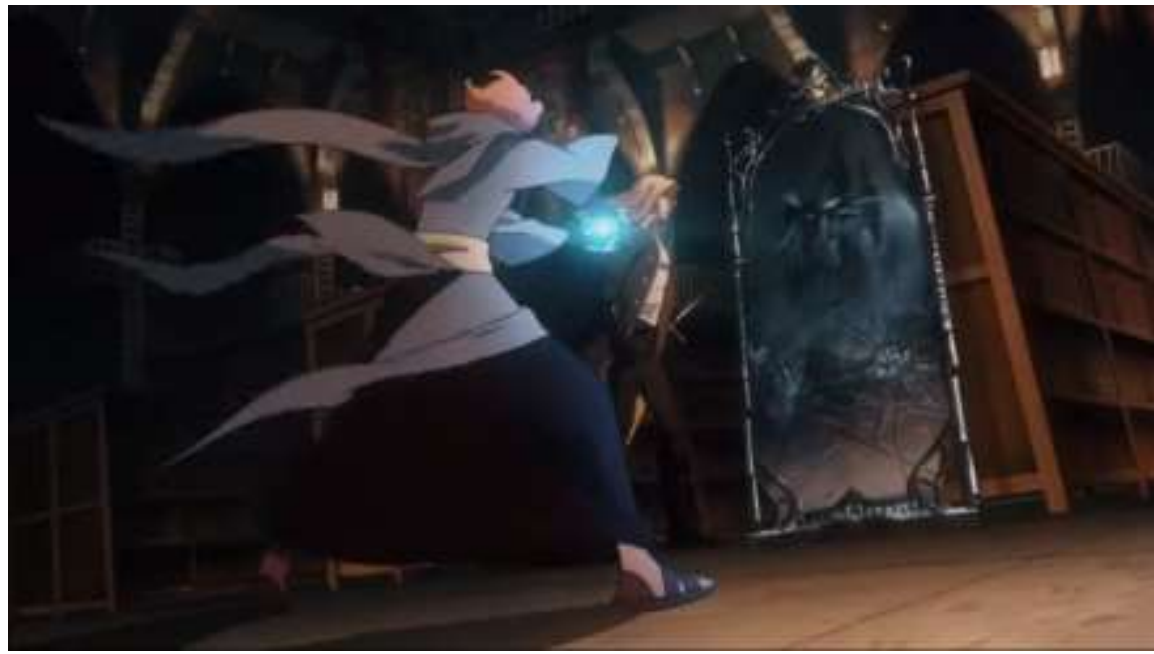

Gambar 3: Sypha berhasil mengunci posisi kastil Dracula dengan bantuan Trevor dan Alucard (Castlevania, "The River").

Dari pemaparan yang sudah ada, dapat disimpulkan bahwa tema utama konflik antara good dan evil tampak saling mendukung dan berhubungan dengan tema-tema tambahan yang sudah dijelaskan di atas. Baik game maupun serial Castlevania mampu menyajikan tema utama dan tema tambahan secara bersamaan tanpa merusak sinergi keduanya dalam cerita.

\title{
Analisis Unsur Intrinsik dalam Alih Wahana Castlevania
}

Sub bab ini akan menjelaskan bagaimana tema utama disajikan dalam alih wahana Castlevania dengan ditinjau dari tiga aspek elemen intrinsik sastra yakni alur, point of view, dan simbolisme.

\begin{abstract}
Alur
Game Castlevania III: Draculas's Curse dan serial adaptasinya Castlevania memiliki jenis alur yang berbeda satu sama lain. Seperti yang sudah disebutkan sebelumnya, alur pada game orisinilnya adalah non-linear, sehingga pemain dapat memilih jalur plot yang tersedia, dan hal ini nantinya akan berdampak pada pilihan pendamping yang bisa direkrut dalam permainan serta akhir cerita yang berbeda.

Dalam prolog game, diceritakan bahwa Dracula mulai mengambil alih benua Eropa dan menghancurkan negara-negara yang ada di dalamnya. Orang-orang Eropa berusaha untuk melawannya, tapi tidak ada yang berhasil bertahan hidup. Akhirnya keluarga Belmont yang legendaris dan termasyhur akan kekuatan supranaturalnya
\end{abstract}


sebagai pemburu vampir didatangkan untuk menghadapi Dracula dan pasukannya yang kejam. Di titik ini, konflik antara kebaikan melawan kejahatan telah dihadirkan dalam game di mana Dracula mewakili kubu evil karena sifatnya yang keji dan jahat. Di sisi lain, Trevor Belmont ditempatkan sebagai protagonis kubu good dengan sifat berani dan heroiknya.

Konflik antara kubu good dan evil berlanjut ketika Trevor pergi menuju kastil Dracula dan memungkinkannya bertemu dengan tiga karakter (tergantung jalur yang diambil oleh pemain) yang dapat mendampinginya: Gant, Sypha, atau Alucard. Ketika Trevor bertemu Gant, pencuri ini awalnya dikutuk menjadi hantu oleh Dracula, sedangkan Sypha dikutuk menjadi patung oleh Cyclops ketika Trevor berhasil membebaskannya. Adapun Alucard sedang beristirahat dari mati surinya ketika Trevor berhasil membangunkan/(melawan-)nya. Dari ketiga peristiwa pertemuan Trevor dengan karakter pendampingnya, dapat diinterpretasikan bahwa konflik antara good dan evil dalam game dapat juga dilihat sebagai pertarungan antara hidup dan mati, yaitu Trevor ingin menghidupkan kembali Eropa yang sudah hancur beserta orang-orangnya yang sudah dikutuk, sedangkan Dracula ingin mempertahankan kutukan dan teror kerusakan yang dia ciptakan.

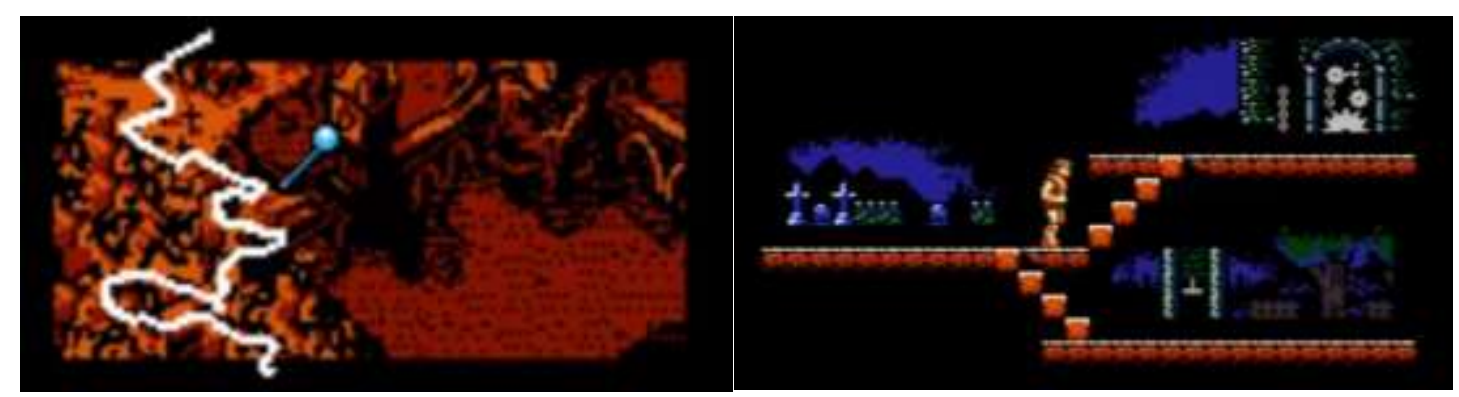

Gambar 4: Pemain game Castlevania III dapat memilih jalur plot (kanan) untuk dijalani.

Di sisi lain, alur pada serial Netflix Castlevania tetap berpedoman pada game orisinilnya dan dikembangkan secara sederhana namun menarik. Ada bagian dalam alur cerita ketika double plot (dua cerita sama penting dan maju secara bersamaan) digunakan, yakni ketika Trevor, Sypha, dan Alucard pergi mencari informasi di kediaman warisan keluarga Belmont, dan di saat yang bersamaan, Dracula bersama dewan vampirnya menyusun strategi untuk menghancurkan Wallachia dan kelompok Trevor. 
Dibandingkan game Castlevania III yang memiliki alur non-linear, serial animasinya memiliki alur maju dengan sedikit cuplikan kilas balik beberapa tokoh seperti Dracula. Penggunaan alur non-linear dalam permainan secara signifkan mempengaruhi jalan dan akhir cerita yang berbeda, karena Trevor hanya dapat merekrut satu karakter pendamping saja dalam satu waktu, dan ketiganya tidak ditemukan pada jalur yang sama, sehingga tidak mungkin bagi pemain untuk bertemu serta mendapatkan Sypha, Alucard, dan Gant semuanya dalam satu permainan. Hal ini tidak terjadi pada serial Netflix-nya karena Trevor senantiasa melakukan perjalanan menuju kastil Dracula bersama Sypha dan Alucard hingga akhir cerita. Hal ini kemudian berdampak pada bagaimana tema utama disajikan dalam alih wahana.

Dalam game, pemain memainkan Trevor sebagai protagonis utama dan hanya didampingi oleh satu karakter pilihan, sedangkan dalam serial Netflix, audiens melihat melalui sudut pandang orang ketiga, terutama Trevor dan kedua pendampingnya. Dalam permainan, Trevor memiliki nyawa dan pendamping yang terbatas, sedangkan dalam serialnya Trevor memiliki pendamping yang lebih lengkap dan penonton tidak terlibat langsung dalam cerita, sehingga hal ini menimbulkan efek krisis dan serius kala memainkan game-nya ketimbang menonton serial animasinya. Jika pemain kehabisan nyawa dalam permainan, maka game akan berakhir dan Dracula menang. Serialnya tidak memberikan ketegangan seperti ini, dan hal ini juga ditegaskan oleh Rouse III (2009) yang menyatakan bahwa saat bermain game pemain memproyeksikan diri mereka ke dalam karakter utama lebih dari wahana lainnya. Oleh karena itu, konklusi yang didapatkan adalah konflik antara good dan evil disajikan lebih kuat pada game orisinilnya karena faktor-faktor tersebut di atas.

\section{Point of View}

Perbedaan alur cerita yang terjadi pada alih wahana dari game ke serial Castlevania bukanlah satu-satunya aspek yang membuat penyajian temanya berbeda. Perubahan juga terjadi pada aspek sudut pandang tokoh atau point of view (pov). Game Castlevania III berisi narasi yang dilihat dari protaganis utama Trevor Belmont, dan dalam beberapa momen dari karakter pendampingnya (Sypha/Alucard/ Gant), sedangkan serial adaptasinya didominasi oleh point of view objektif. Hal ini bisa dilihat dari 
komposisi kemunculan perspektif tokoh antagonis dalam serial seperti Dracula, Godbrand, Carmilla, dan Isaac.

Ketika cerita dalam game Castlevania III dialih wahanakan ke dalam serial Netflix, maka prespektif kamera mewakili mata manusia dalam melihat cerita. Dalam hal ini, ada peralihan signifikan dalam pemakaian point of view orang ketiga terbatas menjadi point of view objektif dalam adaptasinya yang berimbas pada pemaknaan cerita yang berbeda dari game orisinilnya. Tokoh dewa vampir Dracula merupakan contoh istimewa atas perubahan sudut pandang ini, di mana dia ditampilkan tanpa perspektif sama sekali dalam game, namun menjadi salah satu tokoh utama dalam serial Netflix.

Sebagai salah satu antagonis utama dalam game Castlevania III, Dracula tidak memiliki point of view-nya sendiri, karena dia hanya diceritakan melalui prolog atau fokalisator tokoh lainnya seperti Trevor dan Alucard. Hal ini kemudian akan membuat pemain merasa bahwa Dracula adalah seorang musuh yang sangat lalim dan harus dikalahkan. Padahal Dracula yang disajikan melalui prolog atau fokalisator tokoh lain memiliki implikasi yang sangat penting jika dibandingkan dengan penyajian tokohnya yang lebih independen di serial Netflix.

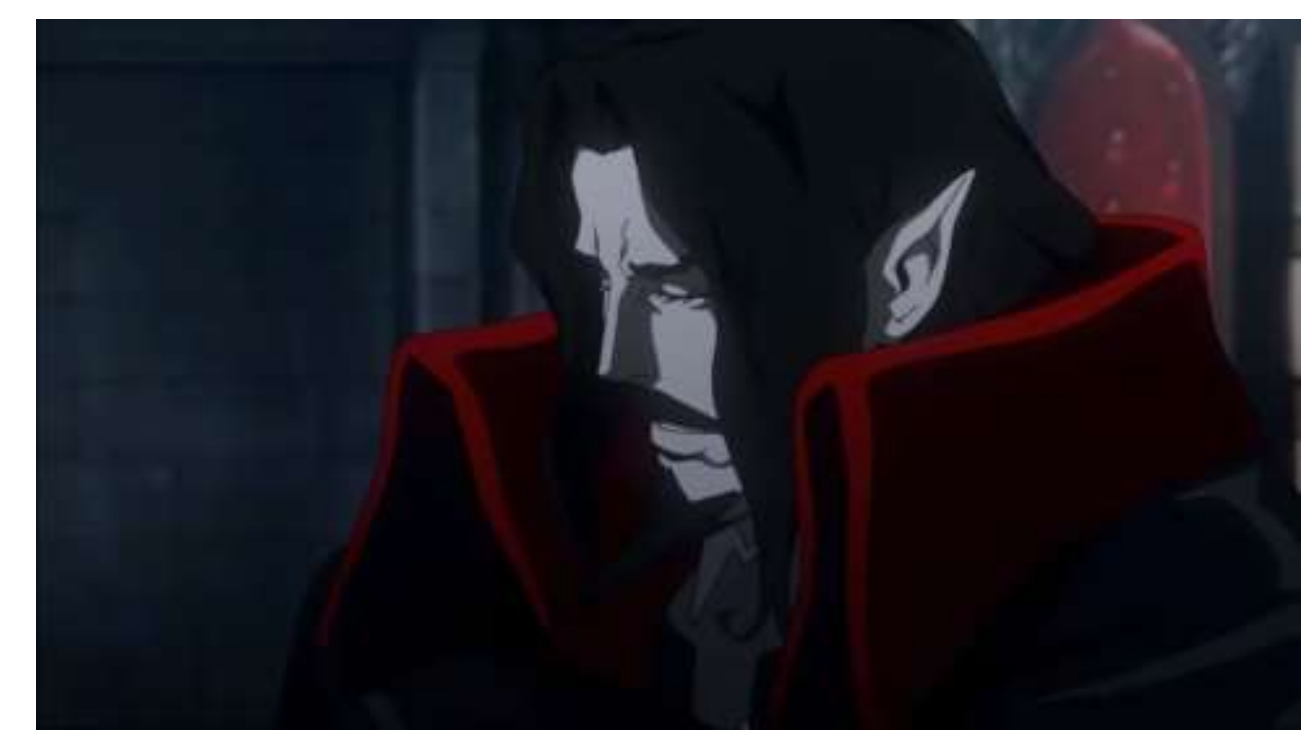

Gambar 5: Dracula dalam serial Netflix memiliki perspektifnya sendiri yang tidak ditemukan dalam game-nya.

Serial Netflix menyajikan Dracula sebagai tokoh antagonis yang lebih hidup dan objektif karena dia tidak terinfiltrasi oleh pandangan dari tokoh lain. Sebagai contoh, ketika pemain meresepsi Dracula dari prolog game, maka pemain melihatnya dari sudut 
pandang penduduk Eropa dan Wallachia yang tertindas. Hal ini jelas menyiratkan bahwa penyajian tokoh Dracula menjadi lebih subjektif. Serial Netflix, sebaliknya, memberikan Dracula adegan demi adegan dimana dia berperan sebagai tokoh yang bertindak dan berpikir sebagai subjek dalam cerita.

Game menceritakan bahwa Dracula melakukan teror di Eropa dan Wallachia, akan tetapi tidak pernah disebutkan apa alasan di balik tindakannya, sedangkan serial adaptasinya menceritakan bahwa dia ingin menghancurkan Wallachia sebagai balasan terhadap kematian istrinya yang dibunuh atas tuduhan yang tidak benar. Hal ini menandakan bahwa Dracula menjadi tokoh yang lebih rasional dan simpatik dalam serial Netflix ketimbang game.

Selain itu, serial juga menunjukkan Dracula yang hendak membunuh Alucard di ruang masa kecilnya tiba-tiba menjadi terganggu dan tersadar akan perbuatannya; game tentunya tidak memiliki cut-scene serupa, dan hal ini bermakna bahwa serial Castlevania memberikan kesempatan bagi Dracula untuk menyuarakan aspirasinya. Dalam pertarungan puncak, game menyajikan Dracula yang bersikap tidak peduli meskipun terhadap anaknya sendiri Alucard, adapun serial Netflix memberikan adegan dramatis bagi Dracula untuk menunjukkan perasaannya yang terdalam: “I'm... I... I'm killing my boy. Lisa. I'm killing our boy. We painted this room. We made these toys. It's our boy, Lisa. Your greatest gift to me and I'm killing him. I must already be dead." (Castlevania, "For Love") 

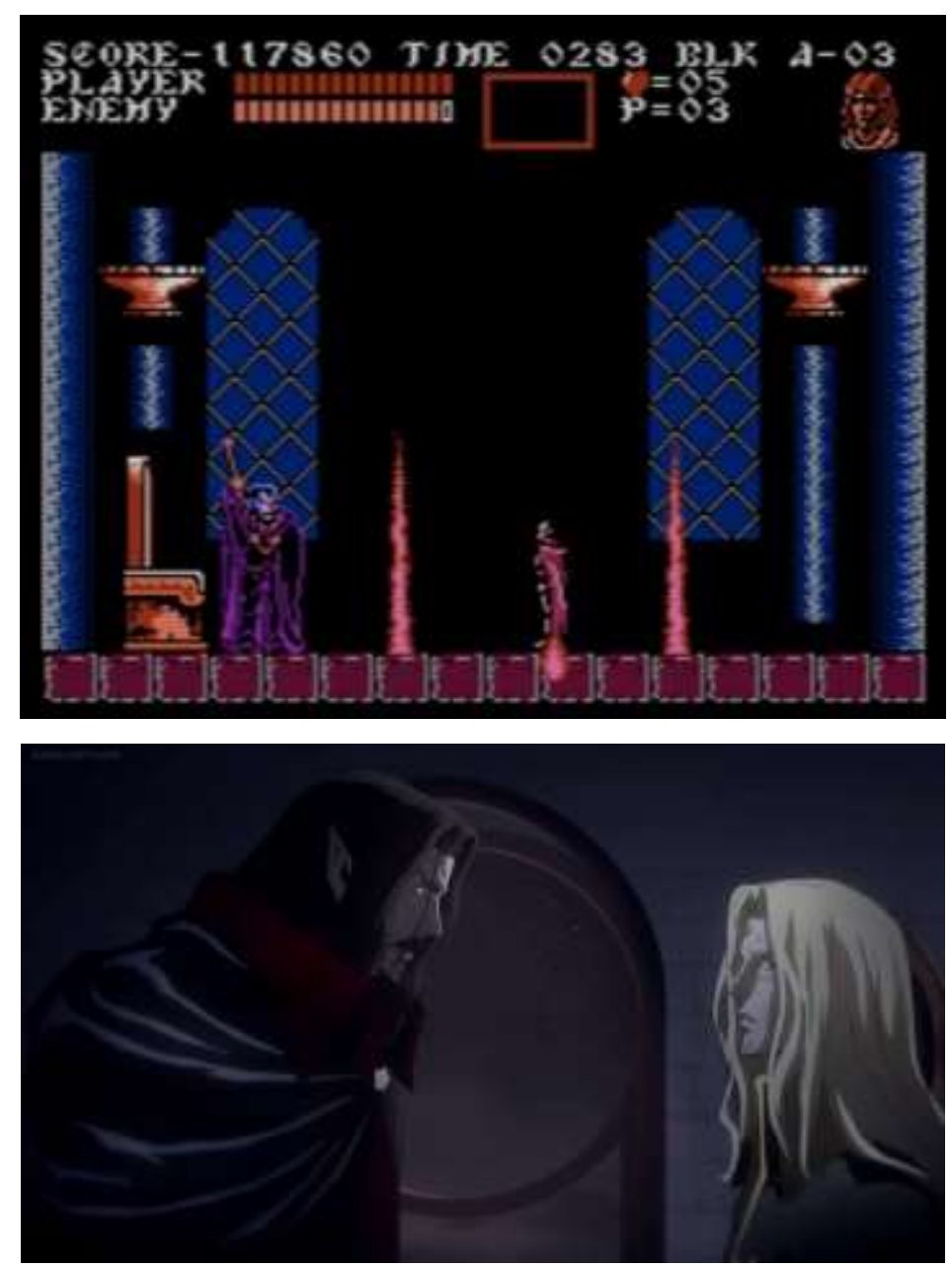

Gambar 6: Pertarungan antara Alucard dan Dracula dalam game (kiri) serta serial Castlevania (kanan).

Perbedaan point of view dalam kedua wahana serta adegan tambahan dalam adaptasinya memperlihatkan bahwa Dracula disajikan sebagai tokoh yang lebih terhormat dalam serial Netflix ketimbang game. Jika dalam game-nya pemain harus bersusah payah mengalahkan Dracula pada pertarungan final, serial adaptasinya menampilkan Dracula yang sudah tersadar pada akhirnya merasa menyesal dan dengan sukarela membiarkan dirinya mati ditusuk sebagai penebusan dosa. Oleh karena itu, jika dihubungkan dengan tema utamanya, maka bisa disimpulkan bahwa konflik antara good dan evil disajikan lebih kuat pada game orisinilnya karena Dracula digambarkan sebagai sosok yang murni jahat dan keji, sedangkan serial Netflix menampilkan Dracula sebagai tokoh yang lebih memiliki perasaan belas kasih.

\section{Simbolisme}


Analisis pada sub-bab simbolisme mengacu pada trikotomi semiotik Peirce (1991) yang mengkategorikan hubungan tanda atau simbol yang ditemukan dalam kedua wahana dengan acuannya ke dalam tiga jenis hubungan, yaitu ikon (hubungan kemiripan), indeks (hubungan kedekatan eksistensi), dan simbol (hubungan yang sudah terbentuk secara konvensi).

Pertama-tama, Nintendo Amerika sudah terkenal karena kebijakan ketatnya dalam hal sensor bermuatan kekerasan, konten seksual, serta bahasa yang tidak senonoh (Steffen et al., 2014). Selain itu, mereka juga cukup selektif pada muatan referensi religi yang cukup terbuka dalam sebuah game, dan karena itulah sebagian besar game NES meniadakan gereja, salib, atau pendeta. Akan tetapi, entah bagaimana game Castlevania berhasil melewati badan sensor Nintendo dan mungkin menjadi salah satu game NES yang secara terang-terangan dipenuhi oleh simbol-simbol religi.

Jika simbol-simbol Kristen seperti salib dan air suci dapat dilihat sepanjang permainan, bagian kredit game Castlevania III menyajikan permainan kata simbolis. Bagian kredit setelah menamatkan game dipenuhi oleh nama-nama aneh seperti: Vran Stoker, Christopher Bee, Trans Fishers, dan Boris Karloffice. Jika dicermati lebih teliti, mereka sebenarnya merupakan ikon dari orang-orang serta pelaku sinema horor gotik. Vran Stoker adalah ikon Bram Stoker (penulis novel Dracula), Christopher Bee ikon dari Christopher Lee (aktor yang berperan sebagai Count Dracula), Trans Fishers merupakan ikon Terence Fisher (sutradara legendaris untuk film-film horor gotik seperti Dracula dan The Curse of Frankenstein), sedangkan Boris Karloffice menjadi ikon dari Boris Karloff (aktor yang beberapa kali memerankan sebagai monster Frankenstein).

Permainan kata yang menjadi ikon dalam kredit game seakan mengukuhkan genre horor gotik dalam Castlevania III, dan hal ini semakin menguatkan tema utamanya yakni konflik antara kebaikan melawan kejahatan yang menjadi salah satu fitur dalam genre tersebut (Jackson, McGillis, \& Coats, 2013). Adapun serial adaptasinya tidak memiliki kredit seperti game orisinilnya.

Dracula menciptakan teror di Eropa dan Wallachia yang menyimbolkan sebuah masa yang mematikan serta mencekam, dan sebagai akibatnya sebagian besar penduduk bersembunyi di balik rumah, jarang terlihat aktivitas kehidupan normal. Teror yang tercipta serta pasukan iblis yang dilepaskan oleh Dracula niscaya telah menghancurkan kehidupan Wallachia dan Eropa. Meskipun teror Dracula tersebut merepresentasikan 
bahwa Wallachia dan Eropa dalam bahaya, di sisi lain, tindakan Dracula juga berperan sebagai pemicu akan terciptanya konflik antara good dan evil.

Ketika Trevor dan kawan-kawan mulai melakukan perlawanan, Wallachia memiliki harapan untuk kembali seperti sedia kala. Proses teror yang mencekam seiring dengan perlawanan Trevor, Sypha, dan Alucard untuk harapan kehidupan merupakan sebuah indeks. Peristiwa ini mengindikasikan sedang terjadinya pergantian masa di Wallachia dan Eropa, yakni dari masa deteriorasi ke masa yang lebih baik. Perisitiwa ini juga dapat dilihat sebagai sebuah perubahan yang tengah dialami Wallachia yang tadinya merupakan simbol dari kekacauan, kini setelah dikalahkannya Dracula, menjadi simbol perdamaian.

Sebagai tambahan, indeks juga dapat ditemukan pada tokoh Alucard dalam serial Netflix. Awalnya Trevor dan Sypha menemukan "prajurit tertidur" bernama Adrian yang telah menghabiskan satu tahun penyembuhan dari pertarungan terakhirnya dengan Dracula. Adrian, yang ternyata seorang dhampir dan anak kandung Dracula, kemudian terlibat pertarungan dengan Trevor. Akan tetapi, setelah melihat tekad Trevor dan Sypha, Adrian mengalah dan menawarkan bantuannya. Dia kemudian mengganti namanya menjadi Alucard, dan pergantian nama ini merupakan indeks karena resolusinya bisa dianggap sebagai bersatunya Alucard dengan kubu good dengan meninggalkan atribut evil-nya.

Terakhir, titel dari game dan serial Netflix Castlevania merupakan simbol dari isi ceritanya. Latar dari kedua wahana seringkali bertempat di dalam kastil gelap yang dipenuhi oleh monster serta makhluk-makhluk supranatural milik Dracula yang kejam dan menyeramkan. Pada dasarnya, Dracula beserta pasukannya yang bengis merupakan simbol dari evil itu sendiri, sedangkan Trevor, Sypha, dan Alucard yang rela berkorban dan tanpa pamrih merupakan simbol dari good.

Sebagai tambahan, beberapa senjata dalam game yang digunakan oleh Trevor dalam petualangannya seperti air suci dan kalung rosario merupakan simbol suci dalam agama Kristen dan merupakan representasi dari good. Adapun Dracula yang memiliki keabadian serta kekuatan sihir dengan menjelma menjadi dewa vampir yang jahat merupakan representasi dari evil. Bahkan dalam game-nya, Dracula memiliki dua transformasi yang harus dikalahkan oleh pemain untuk menamatkan permainan. 

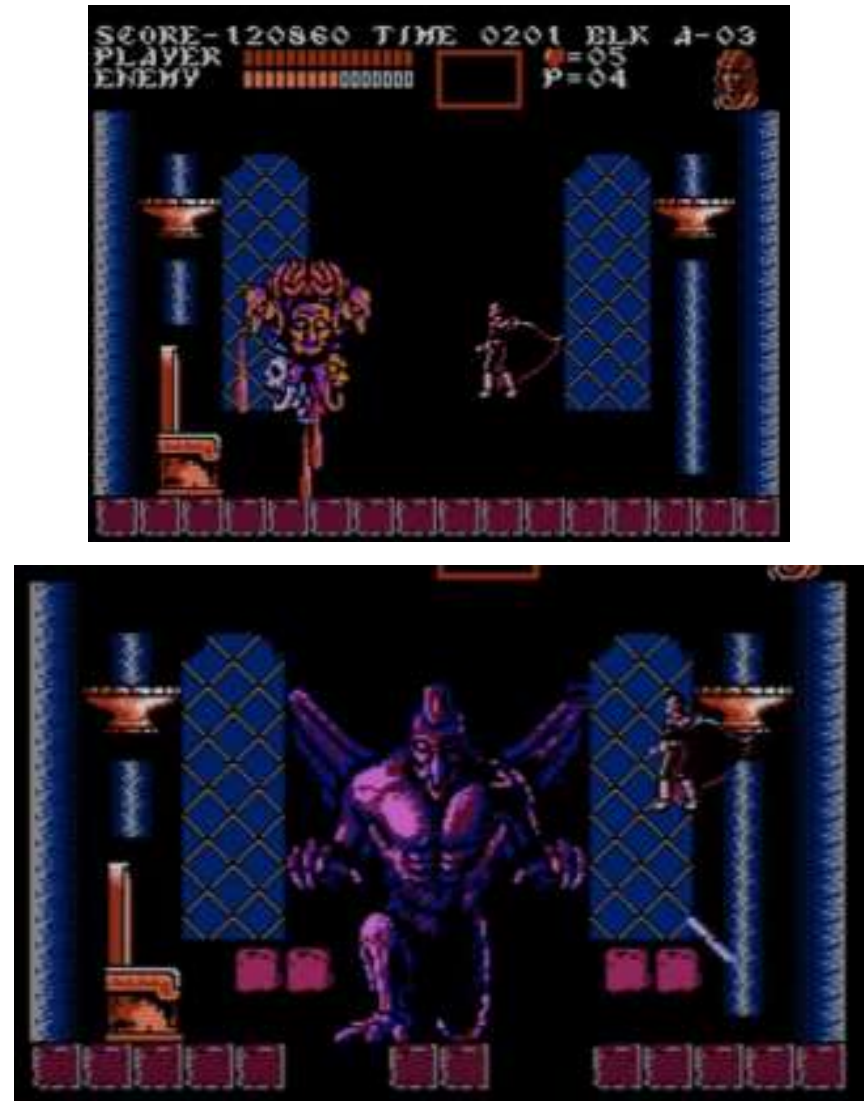

Gambar 7: Wujud transformasi kedua Dracula (kiri) dan wujud ketiganya (kanan) dalam game.

Bentuk kedua Dracula dalam game sangat mungkin manifestasi dari dewa-dewa jahat yang telah memberikan kekuatan kepada sang antagonis, sedangkan bentuk finalnya sangat mirip dengan raja iblis Pazuzu dalam agama Mesopotamia kuno yang menjadi simbol dari roh jahat (Maiden, 2018). Hal ini tentu saja menegaskan ikatan yang begitu kuat antara Dracula dengan kubu evil, dan pada akhirnya berdampak pada penyajian tema dalam alih wahana dimana serial Netflix tidak memiliki transformasi bentuk seperti dalam game-nya, sehingga bisa dideduksi bahwa kubu evil lebih kuat disajikan dalam permainan orisinilnya dibandingkan adaptasinya.

\section{Kesimpulan}

Berdasarkan analisis penyajian tema dalam alih wahana dari game ke serial Castlevania pada bab sebelumnya, dapat penulis sampaikan bahwa tema yang disajikan pada hakikatnya tidak berbeda dari tema umum kisah-kisah horor Gotik lainnya, yakni konflik antara kebaikan melawan kejahatan atau konflik antara good dan evil. Tema 
utama ini disajikan dalam alih wahana dengan memberikan kontras yang jelas di dalam unsur-unsur alur, point of view, dan simbolisme.

Pada akhirnya, setelah ditelaah secara mendalam, alih wahana yang terjadi ternyata memberikan dampak terhadap bagaimana tema utama itu disajikan. Dengan alur non-linear, sudut pandang serta tokoh pendamping yang terbatas, dan kemunculan simbol selama permainan, penulis menarik kesimpulan bahwa tema konflik antara good dan evil disajikan lebih kuat pada game Castlevania III: Dracula's Curse dibandingkan adaptasinya serial Netflix Castlevania.

Alih wahana ini juga menunjukkan bahwa selain tema utama yang lebih kuat dalam game orisinilnya, masyarakat juga telah berubah selama hampir tiga dekade terakhir, dimana game-nya dirilis pada tahun 1990 sedangkan serial Netflixnya ditayangkan tahun 2017 dan 2018. Masyarakat modern menjadi lebih terbuka terhadap tokoh jahat seperti Dracula dan cenderung melihat dari dua sisi seperti yang ditampilkan dalam serial Netflixnya. Namun, mereka tetap merasa bahwa figur jahat dan keji seperti Dracula, apapun motifnya, sudah selayaknya dilenyapkan demi kehidupan yang lebih baik. Akhir kata, alih wahana ini memperlihatkan bahwa legenda tentang Dracula dan vampir tidak akan pernah hilang dan lekang oleh waktu, dan sepertinya akan terus hidup kembali dalam berbagai wahana lainnya. 


\section{Referensi}

Damono, S. D. (2018). Alih Wahana: PT Gramedia Pustaka Utama.

Edwards, B. (2006). Japanese Castlevania III: The Music is Worth it. Vintage Computing Gaming.

Hutcheon, L. (2012). A Theory of Adaptation: Taylor \& Francis.

Jackson, A., McGillis, R., \& Coats, K. (2013). The Gothic in Children's Literature: Haunting the Borders: Routledge.

Jowett, L., Abbott, S., \& Starr, M. (2017). Introduction: Bloodlines: hunting the vampire through TV history. Horror Studies, 8(2).

Maiden, B. (2018). Counterintuitive Demons: Pazuzu and Lamaštu in Iconography, Text, and Cognition. Journal of ancient near eastern religions, 18(1), 86-110.

Martin, P. (2011). Ambivalence and Recursion in Castlevania: Symphony of the Night. Eludamos. Journal for Computer Game Culture, 5(1), 71-90.

Netflix. (2019). Netflix Q1 19 Letter to Shareholders.

Peirce, C. S. (1991). Peirce on signs: Writings on semiotic: UNC Press Books.

Rouse III, R. (2009). Match Made in Hell: The inevitable success of the horror genre in video games. Horror video games: Essays on the fusion of fear and play, 15-25.

Steffen, O., Likarish, P. F., Walter, B. S. G., Abrams, N., Zeiler, X., Anthony, J., . . . Luft, S. (2014). Playing with religion in digital games: Indiana University Press.

Therrien, C. (2009). Games of fear: a multi-faceted historical account of the horror genre in video games. Horror video games: Essays on the fusion of fear and play, 26-45.

Vo, A. (2017). Netflix animated series just lifted a curse: It's the first video game adaptation to get a Fresh rating. Retrieved from https://editorial.rottentomatoes.com/article/netflix-castlevania-broke-rottentomatoes-record/ 